\title{
Development of Example non Example Learning Devices with Visual Thinking Approach in the Set Material of 7th Grade SMP
}

\author{
Fatriya Adamura ${ }^{1, *}$, Wasilatul Murtafiah ${ }^{2}$, Winda Oktasari Budiyanti ${ }^{3}$ \\ ${ }^{1,2,3}$ Univeristas PGRI Madiun, Indonesia \\ ${ }^{*}$ Corresponding author. Email: fatriya.mathedu@ unipma.ac.id
}

\begin{abstract}
This research is a development research that aims to determine the development of example non-example learning devices with a visual thinking approach on the set material of VII ${ }^{\text {th }}$ grade SMP with validity and practicality tests. The type of research used in this research is Research and Development (R\&D) with the ASSURE model, consists of Analyze learner, State objectives, Select methods, media, materials, Require learner participation, Evaluate and revise. The subjects of this study were students of class VII SMPN 2 Geger who were taken samples of 3 students. The instruments used were the Lesson Plan validation sheet and the Student Worksheet, the teacher's response questionnaire to the learning devices and the student worksheet readability response questionnaire for students. Results of this research are: 1) Learning devices for lesson plans and student worksheet after the validity test, the total average value is 4.14 and 4.22 so that it can be declared valid with a percentage of $83 \%$ and $84 \%$ with good and very good criteria, 2) Results of the practicality test of the teacher and student response questionnaires got a total average score of 4.25 and 3.74 so that it can be declared practical with very good criteria.
\end{abstract}

Keywords: Learning Devices, Example Non Example, Visual Thinking Approach

\section{INTRODUCTION}

Education is the most important part in achieving success and balance for national development. In Undang-undang Number 20 of 2003 Pasal 1 concerning the national education system states that education is a conscious and planned effort to create learning conditions and during the learning process so that students are not passive in developing their potential to have religious spiritual strength, self-control, personality, intelligence, morals. noble, as well as the skills needed by him, society, nation and state [4].

National education in Indonesia is currently still in the stage of improvement, considering that the substance that is transformed through the education and learning process is always under pressure from advances in science and technology and society [2]. Especially in the 2013 curriculum, the Indonesian government requires teachers to develop learning devices that teachers can use to design and process classroom situations during the learning process. Learning devices include, among others: Lesson Plans (RPP), Student
Worksheets (LKPD), Learning Outcomes Test (THB) and teaching materials.

The facts in the field obtained by researchers in September-November 2019 at SMPN 2 Geger are that most teachers still use conventional learning approaches or lectures. As well as the lack of teacher stimulus in using learning approaches or models, especially in visual form, for example in set material. This is evidenced in the student learning outcomes expressed by one of the mathematics subject teachers which is caused the teacher's mathematics learning not yet apply a visual method to some material. Most teachers only use a scientific approach in learning devices, causing students tend to be bored and lack the courage of students to convey an idea/idea that they see or observe. Therefore, the researcher choose to conduct research at SMPN 2 Geger to apply a visual thinking learning approach.

From the visual thinking approach, the researcher combines it with a suitable model, namely the example non-example learning model where the teacher provides examples and not examples for students to analyze. The 
researcher choose this example non-example model because it is easy to use in the field, especially in Junior High School (SMP) there are students who are still curious by looking at the school environment and pictures.

One of the materials that can be applied using a visual thinking approach is a set, because a set has an image that requires students to imagine the form of a set and the kinds of sets. Based on this explanation, students must have the ability, one of which is visualization skills. Because by means of visualization can help as problem solving. According to [8], visualization is part of visual thinking. Visual thinking is a person's activity that can generate new images and opinions. These forms make the meaning of abstract concepts visible. According to [1], this visual thinking approach is a learning approach that is suitable for mathematics that is good, precise, varied, and can be used to improve understanding of mathematical concepts. Because in learning mathematics the teacher must be able to choose an approach that is in accordance with the material to be delivered.

There are several roles of visual thinking based on the theory of [1], including: to understand problems, with the intention that students can understand mathematical concepts by presenting problems visually; to simplify the problem, which means that students can identify problem solving on understanding the concepts given by the teacher; to see connection problems; to understand student learning styles, because each student has different learning styles; as a substitute for calculation, meaning that students can solve problems directly without calculating using visuals; as a tool for checking solutions, and for verifying the correctness of answers by means of a visual; and to change problems in mathematics, meaning that in mathematical form can be obtained from visuals in problem solving. The steps for visual thinking are:

a. Looking, students analyze an existing problem and there is a reciprocal relationship, it is an activity of seeing, reasoning, and collecting.

b. Seeing, students can understand problems and have opportunities, by selecting and grouping activities.

c. Imagining, generalizing steps to find a solution, with pattern activities.

d. Showing and telling, explaining what students see and then communicating.

The visual thinking approach can be applied through a learning model. One of these learning models is the example non example cooperative learning model. According to [7] example non-example is a learning model that involves students to analyze pictures, photos, or problems given by the teacher which also contains various examples and non-examples included in the material. This non-example aims to train students to think critically in solving problems in mathematics. According to [6], it means that the example nonexample model is a mathematics learning model that uses images as a tool to convey material to students with the teacher preparing examples and not examples according to the material. The example non example cooperative learning model prioritizes students to analyze an example, picture, or problem they see, then discuss it with the group and the results are presented to other groups. The purpose of this model is that students are able to analyze a concept that has been studied according to their own ideas or opinions.

Research [7] uses the Assure model to develop mathematics learning media. [10] also said that visual thinking with a contextual approach can strengthen the nation's character. In addition, [11] also shows that the example non example learning model can improve student learning outcomes. Some of these studies indicate that it is necessary to develop student activity sheets with the Example Non Example model with a Visual Thinking approach on the set material for Class VII SMP.

Based on the description above, the researchers conducted a study entitled "Development of Example Non-Example Learning Devices with a Visual Thinking Approach in Set Materials of $7^{\text {th }}$ Grade Junior High School ". This research aims to determine the development of example non-example learning devices with a visual thinking approach on the material set for class VII SMP.

\section{RESEARCH METHOD}

This research is a product development. The product resulting from this research is in the form of learning devices consisting of: Lesson Plan and Student Worksheets that use an example non-example learning model with a visual thinking approach to the material set for class VII SMP. This research model uses the ASSURE model, including Analyze learner, State objectives, Select methods, media, materials, Ultilize learner participation, Evaluate and revision. However, in this study at the fifth stage, namely, require learner participation was not implemented. Due to current conditions during the corona virus pandemic, it is not possible for students to be directly involved in this research [5].

Sources of data in this study there are three validators, namely one UNIPMA mathematics lecturer, one mathematics teacher who teaches class VII SMP and one junior high school mathematics teacher. In this study, using the RPP and LKPD validation sheets to test the validity and the teacher response questionnaire and LKPD readability sheets to test the practicality of the learning devices that have been developed. 


\section{RESULTS AND DISCUSSION}

\subsection{Validation of Learning Devices}

\subsubsection{RPP Validattion Results}

To find out the validity of the RPP that has been developed, if the results of the validation have not reached the specified results, the researcher revises the RPP product in accordance with the suggestions or comments from the three validators. If there is no revision, then the lesson plans can be used or applied in the classroom environment. To process the RPP validation data, the researcher uses the formula from [3].

$$
V=\frac{T S_{e}}{T S_{h}} \times 100 \%
$$

Then the researcher can perform the validity of results of the average formula as follows:

$$
V=\frac{V_{1}+V_{2}+\cdots}{n}=\cdots \%
$$

Information:

$\mathrm{V}=$ Percentage

$\mathrm{TSe}=$ Total score $($ sum of assessment score from validator)

$\mathrm{TSh}=$ Total expected score (maximum total score of each validator)

Researchers to find out the results of the percentage of RPP from the three validators can be seen in table 1:

Table 1. Results of Percentage of RPP

\begin{tabular}{|c|c|c|c|c|}
\hline Validator & $\begin{array}{c}\text { Total } \\
\text { Score }\end{array}$ & $\begin{array}{c}\text { Total } \\
\text { Expected } \\
\text { Percentage }\end{array}$ & $\begin{array}{c}\text { Valid } \\
\text { Percentage }\end{array}$ & $\begin{array}{c}\text { Combined } \\
\text { Percentage }\end{array}$ \\
\hline 1 & 164 & 205 & $80 \%$ & \multirow{2}{*}{$83 \%$} \\
\hline 2 & 190 & 205 & $93 \%$ & \multirow{2}{*}{$83 \%$} \\
\hline 3 & 155 & 205 & $76 \%$ & \\
\hline
\end{tabular}

Based on the results of table 1, the researchers obtained the results of the percentage of RPP, namely $83 \%$ so that it can be declared valid. As for the assessment of the RPP validation sheet conducted by mathematics lecturers and mathematics teachers at SMPN 2 Geger. To determine the level of instrument validity, the researchers performed calculations with the analysis of the validity of the lesson plans with the results as table 2 :

\begin{tabular}{|c|c|c|c|c|c|}
\hline Validator & $\begin{array}{c}\text { Total } \\
\text { Score Per } \\
\text { Validator }\end{array}$ & $\begin{array}{c}\text { Average } \\
\text { Per } \\
\text { Validator }\end{array}$ & $\begin{array}{c}\text { Criteria } \\
\text { Per } \\
\text { Validator }\end{array}$ & $\begin{array}{c}\text { Average } \\
\text { Score } \\
\text { Total }\end{array}$ & $\begin{array}{r}\text { Overall } \\
\text { Criteria }\end{array}$ \\
\hline 1 & 164 & 4,0 & Good & \multirow{3}{*}{4,14} & \multirow{3}{*}{ Good } \\
\hline 2 & 190 & 4,6 & Good & & \\
\hline 3 & 155 & 3,8 & Good & & \\
\hline
\end{tabular}

Table 2. Results of RPP Validation
Based on the results of the analysis in table 2, the total average is 4.14 which indicates that the validity of the lesson plans is good and can be declared valid.

\subsubsection{LKPD Validation Results}

The LKPD learning device validation activity was carried out by three validators to determine the validity of the LKPD developed by researchers. If the results of the validation have not reached the specified results, the researcher revises the LKPD in accordance with the comments or suggestions from the validator. If there is no revision, then the LKPD can be used and applied to students. To process the researcher's LKPD validation data using the formula from [3], the researchers obtained data from the LKPD validation results in table 3:

Table 3. LKPD Percentage Results

\begin{tabular}{|c|c|c|c|c|}
\hline Validator & $\begin{array}{c}\text { Total } \\
\text { Score }\end{array}$ & $\begin{array}{c}\text { Total } \\
\text { Expected }\end{array}$ & $\begin{array}{c}\text { Valid } \\
\text { Percentage }\end{array}$ & $\begin{array}{c}\text { Combined } \\
\text { Percentage }\end{array}$ \\
\hline 1 & 75 & 90 & $83 \%$ & \multirow{2}{*}{$84 \%$} \\
\hline 2 & 82 & 90 & $91 \%$ & \\
\hline 3 & 71 & 90 & $79 \%$ & \\
\hline
\end{tabular}

Based on table 3 , the researchers obtained the combined percentage results were $84 \%$ in the valid criteria. Meanwhile, to determine the level of validity of the LKPD instrument by analyzing the validity of the LKPD with the results in table 4 :

\begin{tabular}{|c|c|c|c|c|c|}
\hline Validator & $\begin{array}{c}\text { Total } \\
\text { Score Per } \\
\text { Validator }\end{array}$ & $\begin{array}{l}\text { Average } \\
\text { Per } \\
\text { Validator }\end{array}$ & $\begin{array}{c}\text { Criteria } \\
\text { Per } \\
\text { Validator }\end{array}$ & $\begin{array}{c}\text { Average } \\
\text { Total } \\
\text { Score }\end{array}$ & $\begin{array}{l}\text { Overall } \\
\text { Criteria }\end{array}$ \\
\hline 1 & 75 & 4,17 & Good & \multirow{3}{*}{4,22} & \multirow{3}{*}{$\begin{array}{l}\text { Very } \\
\text { Good }\end{array}$} \\
\hline 2 & 82 & 4,6 & Good & & \\
\hline 3 & 71 & 3,94 & Good & & \\
\hline
\end{tabular}

Table 4 LKPD Validation Results

\subsection{Practicality of Learning Devices}

\subsubsection{Teacher Response Results}

The assessment of the teacher response questionnaire sheet was carried out by two practitioners by the mathematics teacher of SMPN 2 Geger. To determine the level of practicality of the instrument, the researchers carried out calculations by analyzing the practicality of the teacher's response with the results in table 5:

Table 5. Results of Practical Analysis of Teacher Responses

\begin{tabular}{|c|c|c|c|c|c|}
\hline $\begin{array}{c}\text { Respon- } \\
\text { dents }\end{array}$ & $\begin{array}{c}\text { Score Total } \\
\text { Respondents }\end{array}$ & $\begin{array}{c}\text { Average } \\
\text { Per } \\
\text { Respon- } \\
\text { dent }\end{array}$ & $\begin{array}{c}\text { Criteria } \\
\text { Per } \\
\text { Respondent }\end{array}$ & $\begin{array}{c}\text { Average } \\
\text { Score } \\
\text { Total }\end{array}$ & $\begin{array}{c}\text { Overall } \\
\text { Criteria }\end{array}$ \\
\hline 1 & 47 & 4,7 & $\begin{array}{c}\text { Very } \\
\text { Good }\end{array}$ & \multirow{2}{*}{4,25} & $\begin{array}{c}\text { Very } \\
\text { Good }\end{array}$ \\
\hline 2 & 38 & 3,8 & $\begin{array}{c}\text { Very } \\
\text { Good }\end{array}$ & & \\
\hline
\end{tabular}


Based on the results of the analysis of the teacher's response to the learning devices developed by the researcher, the average response of the two teachers was 4.25 , which indicates that the assessment is in very good criteria and can be declared practical.

\subsubsection{Student Response Results}

To find out the practicality of the instrument, the researchers carried out calculations by analyzing the practicality of the LKPD readability response with the results in table 6 :

Table 6 Results of the Practicality of Readability Responses

\begin{tabular}{|c|c|c|c|c|c|}
\hline $\begin{array}{l}\text { Respon- } \\
\text { dents }\end{array}$ & $\begin{array}{l}\text { Average } \\
\text { Score } \\
\text { Per } \\
\text { Respon- } \\
\text { dent } \\
\end{array}$ & $\begin{array}{c}\text { Average } \\
\text { Per } \\
\text { Respondent }\end{array}$ & $\begin{array}{c}\text { Criteria } \\
\text { Per } \\
\text { Respondent }\end{array}$ & $\begin{array}{c}\text { Average } \\
\text { Score } \\
\text { Total }\end{array}$ & $\begin{array}{l}\text { Overall } \\
\text { Criteria }\end{array}$ \\
\hline 1 & 33 & 3,67 & $\begin{array}{l}\text { Very } \\
\text { Good }\end{array}$ & \multirow{3}{*}{3,74} & \multirow{3}{*}{$\begin{array}{l}\text { Very } \\
\text { Good }\end{array}$} \\
\hline 2 & 34 & 3,8 & $\begin{array}{l}\text { Very } \\
\text { Good }\end{array}$ & & \\
\hline 3 & 34 & 3,8 & $\begin{array}{l}\text { Very } \\
\text { Good }\end{array}$ & & \\
\hline
\end{tabular}

Based on the results of the LKPD readability response analysis for students in table 6 , the total average value of the three students is 3.74 which indicates that the assessment is in very good criteria based on the criteria and can be declared practical.

\subsection{Discussion}

The process in developing this learning devices use the ASSURE model guidelines which consists of six phases, namely the phase of analyzing the student's character; formulating learning objectives; choosing methods, media and teaching materials; using media and teaching materials; develop student participation; assess and improve. However, in this study it was limited to five phases, at the phase of requiring learner participation it was not used, because it was during the corona virus pandemic. The learning devices developed by the researcher are the Lesson Plan and Student Worksheets.

The description of the research results that have been described previously by the researcher describes the steps of developing an example non example learning device with a visual thinking approach. The results of the development of learning devices in the form of final products that have been tested for validity and practicality are as follows:

\subsubsection{Validity of Learning Devices}

At the evaluation stage, the learning devices developed were the validation of one mathematics lecturer, one mathematics teacher for class VII, and one junior high school mathematics teacher. The indicators for the developed learning devices that were declared valid were construction validity and content validation by experts and two practitioners. The validation of the example non-example learning model with a visual thinking approach can be seen from the assessments of the three validators, the validity level of the Learning Implementation Plan (RPP) is in good criteria with a total average value of 4.14; while the level of validity of the Student Worksheet (LKPD) is in very good criteria with a total average score of 4.22 .

This shows that the learning devices that have been developed are valid based on content, construct, and discussion according to the 2013 curriculum syllabus with set and EYD materials. Based on the results of the percentage of RPP and LKPD the researcher obtained a combined percentage value of $83 \%$ for RPP and $84 \%$ for LKPD, then based on [3] theory, it can be stated that the learning tool is valid.

\subsubsection{Practicality of Learning Devices}

The learning devices developed are said to be practical, it can be seen from the teacher's response questionnaire and the LKPD readability response questionnaire for students. From the results of the teacher response analysis, it was found that the total average value of the two mathematics teachers as respondents was 4.25 with very good criteria. Meanwhile, from the results of the LKPD readability response analysis for students, the average value of the three seventh grade students of SMP was 3.74 with very good criteria. So that the example non example learning device with the visual thinking approach developed by the researcher is said to be practical or easy to use based on the theory of [3].

Based on development results of example non example learning devices with visual thinking approach, it can be described characterizes of learning devices have been developed as follow: using visual thinking approach must be followed by applying the steps for visual thinking. Those are, looking, seeing, imagining, showing and telling. In looking phase, students analyze an existing problem and there is a reciprocal relationship, in seeing phase, students can understand problems and have opportunities, in imagining phase, generalizing steps to find a solution, with pattern activities, in showing and telling phase, student explaining what students see and then communicating.

In other hand, the visual thinking approach can be applied through example non example learning model. Example non-example is a learning model that involves students to analyze pictures, photos, or problems given by the teacher which also contains various examples and non-examples included in the material. This example .non-example aims to train students to think critically in solving problems in mathematics. Characterize of learning devices have been developed is prioritizes 
students to analyze an example, picture, or problem they see, then discuss it with the group and the results are presented to other groups because the purpose of the learning model in development is that students are able to analyze a concept that has been studied according to their own ideas or opinions.

\section{CONCLUSION}

After the researchers conducted a validity test and practicality test, from the Lesson Plan and Student Worksheet developed using the example non example model with a visual thinking approach, the total average value for the Lesson Plan and Student Worksheet was 4.14 and 4.22. It could be declared valid with a percentage of $83 \%$ and $84 \%$ with good and very good criteria. Meanwhile, for the practicality test, the teacher and student responses got a total average score of 4.25 and 3.74 so that it can be declared practical with very good criteria. The advantages of the product being developed for students, teachers, and researchers. For students, students can use the resulting Student Worksheet (LKPD) as a study guide and practice math problems independently at home. For teachers, teachers can use learning devices as discourses to increase teacher innovation and creativity in developing learning devices in the form of Lesson Plan and Student Worksheet that can be applied at SMPN 2 Geger. For researcher, researchers can add insight in the development of devices and can increase the creativity of researchers according to the material and interests of students

\section{REFERENCES}

[1] Ariawan, R. (2017). Pengaruh Pembelajaran Visual Thinking Disertai Aktivitas Quick on the Draw Terhadap Kemampuan Pemecahan Masalah Dan Komunikasi Matematis. Jurnal Penelitian dan Pembelajaran Matematika, 10(1), 1-16. https://doi.org/10.30870/jppm.v10i1.1193

[2] Busro, M., \& Siskandar. (2017). Perencanaan dan Pengembangan Kurikulum. Yogyakarta: Media Akademi.
[3] Fadhliani, H., \& Witri, G. (2018). Developing English Lesson Plans Based on Discovery Learning in Teaching Descriptive Text for the First Year Students of SMP. 978-979.

[4] Habra, T. B. Al, Apriandi, D., \& Adamura, F. (2018). Pengembangan Media E-Learning Berbasis Literasi Untuk Sekolah Menengah Kejuruan. 172-177.

[5] Hasyim, A. (2016). Metode Penelitian Dan Pengembangan di Sekolah. Yogyakarta: Media Akademi.

[6] Miftahul Huda, M. P. (2013). Model-Model Pengajaran dan Pembelajaran. Yogyakarta: Pustaka Pelajar.

[7] Purwanti, B. (2015). Pengembangan Media Video Pembelajaran Matematika dengan Model Assure. Jurnal Kebijakan Dan Pengembangan Pendidikan, 3(1), 42-47. http://ejournal.umm.ac.id/index.php/jmkpp/article/ view/2194

[8] Shoimin, A. (2016). 68 Model Pembelajaran Inovatif dalam Kurikulum 2013. Yogyakarta: ArRuzz Media.

[9] Sumarni, \& Prayitno, A. T. (2016). Kemampuan Visual-Spatial Thinking Dalam Geometri Ruang Mahasiswa Universitas Kuningan. JES-Mat, 2(2), 81-100

[10] Surya, E. (2012). Visual thinking, mathematical problem solving and self- regulated learning with contextual teaching and learning approach edy surya. Jurnal Penelitian Dan Pembelajaran Matematika, 5.

[11] Yensy, N. A. (2012). Penerapan Model Pembelajaran Kooperatif Tipe Example Non Example Dengan Menggunakan Alat Peraga Untuk meningkatkan Hasil Belajar Siswa Di Kelas VIII SMP Negeri 1 Argamakmur. Exacta, 10(1), 24-35. 